\title{
Sustainability: An Exercise in Futility
}

\author{
Mark Morris \\ Independent Researcher \\ King of Prussia, PA 19406, USA \\ E-mail: Mmorris581@comcast.net
}

Received: July 17, 2011

Accepted: August 22, $2011 \quad$ Published: January 16, 2012

doi:10.5539/ijbm.v7n2p36

URL: http://dx.doi.org/10.5539/ijbm.v7n2p36

\begin{abstract}
Over the last twenty years there has been an increase in activity regarding the concept of sustainability. For example, The US EPA announced last year that the agency's policies are going to be driven by sustainability (Cone, 2010). What is sustainability exactly?

In the history of sustainability, the theme of overpopulation, prophecies of exhaustion or shortages of natural resources and cataclysmic consequences for mankind is a consistent in the concept of sustainability. Sustainable development suffers from the problems of being vaguely defined, having as many at seventy different definitions of sustainable development and that it would be virtually impossible to predict the needs of future generations (Taylor, 2002, p. 2). It is for these reasons why the notion of sustainability, in its current form, is an exercise in futility.
\end{abstract}

Keywords: Sustainability, History, Technology, Diffusion, Innovation

The concept of sustainability is not a new concept with the United States. One of the first examples of sustainability was found in the Colonial period. In 1822, various regulations were passed to assure that a specific species of tree used in building of war ships were protected from depletion. There were contemporary statements made that particular species of tree was in danger of being depleted (Williamson, 1945, p. 98). At the time when these protective measures were enacted, there was no foresight by than in less than twenty five years that mass production of steel would be invented. This is just one example of how changes in technological innovation renders the concept of sustainability as unobtainable since foresight into the needs of natural resources for future generations is nearly impossible.

Sustainability cannot be a solution towards the conservation of natural resources for future generations because of vague and numerous definitions. It is not possible to determine what resources will be demanded in the future due to the rapid changes in technology which determines the need for natural resources. An example of changes in technology is when kerosene replaced the need for whale oil which was used for lighting purposes.

\section{History of sustainability}

A definitive start date of sustainable development is uncertain, but there have been several events that proponents of sustainable development have attributed to its beginnings. When examining the literature, Thomas Malthus' theory of population was a major influence to the concept of sustainability.

\subsection{Thomas Malthus-An Essay on the Principles of Population}

One of the first scholars to touch on the subject of sustainable development was Thomas Malthus. In his book An Essay on the Principle of Population, Malthus postulated that the dangers of population growth would preclude the inevitable progress towards a utopian society. Malthus stated "The power of population is indefinitely greater than the power in the earth to produce subsistence for man"(Malthus, 1826). See Figure 2 for a graphical depiction of this relationship. This is the first theory that would suggest that population growth would outpace the ability of the earth to supply resources.

\subsection{Arthur Pigou-Wealth and Welfare}

Another scholar that is credited in early development of sustainable development as a concept was Arthur Pigou. In his book Wealth and Welfare, he originated the idea that governments can, via a mixture of taxes and subsidies, correct perceived market failures or "internalized externalities" (Pigou A. C., 1912). Pigovian Taxes, taxes used to 
correct negative externalities, are named after him. A "pollution tax" would be an example of a Pigovian Tax. Pigou was the first to suggest that human activity was the source of pollution and that a correction, via tax, was needed to balance between this pollution and tax on human activity.

\subsection{Rachel Carson-Silent Spring}

The publication of Rachel Carlson's Silent Spring was a watershed moment in the environmental movement in the United States. The primary purpose of the book was to instill fear into the population regarding pesticide, especially dichlorodiphenyltrichloroethane or DDT and other synthetic chemicals using claims based upon selectively presented suspect scientific evidence about harm to wildlife. Silent Spring was the first modern example of environmental alarmism, with an impact that resulted in one of the first new acts for the newly-formed United States Environmental Protection Agency (EPA) to ban DDT in 1972. In its early years, the EPA had little scientific capability or understanding-indeed; now the familiar scientific disciplines relied on to inform regulations were in their infancies. DDT is a very effective and inexpensive means of controlling the mosquito population that spreads the disease malaria. Improved understanding of how DDT works have shown that, were it not banned, it effectively controls mosquitoes when applied at much lower concentrations that were used to deleterious effect in the post-war period. Since the ban, millions of lives have been lost because alternative products are less effective and more expensive to manufacture, a concern when most countries that have a high prevalence of malaria are very poor. Consequently the World Health Organization reversed its position on DDT and endorsed widespread use of the insecticide to help combat malaria (Wall Street Journal Editioral Staff, 2009).

\subsection{The Population Bomb}

The Population Bomb was a best-selling book written by Paul Ehrlich in 1968. It warned of the mass starvation of humans in the 1970s and 1980s due to overpopulation, as well as other major societal upheavals, and advocated immediate action to limit population growth (Ehrlich, 1968). Even though the predictions behind this book did not come to fruition, the authors still claim that basic premise is valid (Ehrlich \& Ehrlich, The Population Bomb Revisited, 2009, p. 63). Ehrlich states that "humanity has reached a dangerous turning point in its domination of the planet" (Ehrlich \& Ehrlich, The Population Bomb Revisited, 2009, p. 68). In addition "The same genius that allowed us to achieve that dominance must now be harnessed if we are to prevent from sealing our doom" (Ehrlich \& Ehrlich, The Population Bomb Revisited, 2009, p. 68). As one can see, that population control is a central idea in the concept of sustainable development.

\subsection{Club of Rome-The Limits of Growth}

The Club of Rome published a book in 1972 entitled The Limits to Growth. The fundamental argument in this book was that technological development and societal increase cannot continue to grow at an exponential rate as it has been for the past 300 years(Meadows, 2004)(Mitcham, 1995, p. 314). See Figure 3 for a graphical depiction of this relationship. This book was followed by a second book entitled Mankind at the Turning Point in 1974. The explicit message of this book was that human beings had to stop what they were doing and replace growth with a no-growth or steady state economy.

\section{United Nations}

\subsection{Our Common Future}

The Brundtland Commission, formally the World Commission on Environment and Development (WCED) was convened by the United Nations in 1983. The commission was created to address growing concern "about the accelerating deterioration of the human environment and natural resources and the consequences of that deterioration for economic and social development"(World Commission On Environment and Development, 1987). In establishing the commission, the UN General Assembly recognized that environmental problems were global in nature and determined that it was in the common interest of all nations to establish policies for sustainable development. This was one of the first examinations of the concept of sustainable development. The Commission defines sustainable development as follows: "Humanity has the ability to make development sustainable - to ensure that it meets the needs of the present without compromising the ability of future generations to meet their needs" (World Commission On Environment and Development, 1987, p. 8). There are several other troubling suggestions that are contained within the Commission's work. One suggestion is the concept of wealth sharing with poorer nations (World Commission On Environment and Development, 1987, pp. 8, 50-51). Another suggestion that is troubling is that sustainability must be guaranteed ahead of the global economy (World Commission On Environment and Development, 1987, p. 17). In addition, the concept of population control is introduced in order to "reduce the burden to the Earth"(World Commission On Environment and Development, 1987, p. 56). Finally, the concept of collectivism is introduced as a method to control the concert of activity that 
pertains to sustainable development (World Commission On Environment and Development, 1987, pp. 316-318)(Morris, 2002, p. 109).

\subsection{Rio Declaration or Agenda 21}

The first instance of the United Nations incorporating sustainability into the global environmental legal structure was with Agenda 21. Agenda 21 was introduced at the 1992 United Nations Conference on Environment and Development (also known as Earth Summit or UNCED). Agenda 21 is a program run by the United Nations that pertains to sustainable development issues. Proponents claim that Sustainable Development ties together concern for the" carrying capacity of natural systems "with the social challenges facing humanity. Figure one shows a graphical depiction of the generally accepted concept of sustainability. The Rio Declaration on Environment and Development or the Rio Declaration was produced at the same Earth Summit. The Rio Declaration consisted of 27 principles intended to guide future sustainability development around the world.

\subsection{The Hannover Principles}

The Hannover Principles is a set of statements about designing buildings and objects with forethought about their environmental impact, their effect on the sustainability of growth, and their overall impact on society. They were first formulated by William McDonough and Michael Braungart for planning the 2000 World Expo.

These principles are:

- Insist on the right of humanity and nature to co-exist in a healthy, supportive, diverse and sustainable condition.

- Recognize interdependence. The elements of human design interact with and depend upon the natural world, with broad and diverse implications at every scale. Expand design considerations to recognize even distant effects.

- $\quad$ Respect relationships spirit and matter. Consider all aspects of human settlement, including community, dwelling, industry and trade, in terms of existing and evolving connections between spiritual and material consciousness.

- Accept responsibility for the consequences of design decisions upon human well-being, the viability of natural systems and their right to co-exist.

- Create safe objects of long-term value. Do not burden future generations with requirements for maintenance or vigilant administration of potential dangers due to the careless creation of products, processes or standards.

- Eliminate the concept of waste. Evaluate and optimize the full life cycle of products and processes to approach the state of natural systems, in which there is no waste.

- $\quad$ Rely on natural energy flows. Human designs should, like the living world, derive their creative force from perpetual solar income. Incorporate this energy efficiently and safely for responsible use.

- Understand the limitation of design. No human creation lasts forever, and design does not solve all problems. Those who create and plan should practice humility in the face of nature. Treat nature as a model and mentor, not as an inconvenience to be evaded or controlled.

- Seek constant improvement by the sharing of knowledge. Encourage direct and open communication between colleagues, patrons, manufacturers and users to link long-term sustainable considerations with ethical responsibility and to reestablish the integral relationship between natural processes and human activity (McDonough \& Braungart, 2003, pp. 10-11).

The original document states: "The Hannover Principles should be seen as a living document committed to the transformation and growth in the understanding of our interdependence with nature, so that they may adapt as our knowledge of the world evolves"(McDonough \& Braungart, 2003, p. 10).

\section{Sustainability in Use Today}

\subsection{US Environmental Protection Agency-Smart Growth}

One example of sustainability in use today is the concept of Smart Growth. This ideal is being heavily promoted by local, state and federal agencies. According to US EPA, "Smart growth is development that serves the economy, the community, and the environment. It changes the terms of the development debate away from the traditional growth/no-growth question to how and where should new development be accommodated"(United States Environmental Protection Agency, 2001). Smart growth is development that simultaneously achieves: 
- Economic development and jobs - that create employment and business opportunities, improves local tax base, provides neighborhood services and amenities, and creates economically competitive communities.

- Strong neighborhoods - that provide a range of housing options giving people the opportunity to choose housing that best suits them. Smart growth provides the choice to walk, ride a bike, take transit, or drive. It maintains and enhances the value of existing neighborhoods and creates a sense of community.

- Healthy communities - provide families with a clean environment. Smart growth balances development and environmental protection - accommodating growth while preserving open space and critical habitat, reusing land, and protecting water supplies and air quality(United States Environmental Protection Agency, 2001).

\subsection{Principles of Smart Growth}

- $\quad$ Mix land uses

- Take advantage of compact building design

- Create a range of housing opportunities and choices

- Create walkable neighborhoods

- Foster distinctive, attractive communities with a strong sense of place

- Preserve open space, farmland, natural beauty, and critical environmental areas

- Strengthen and direct development towards existing communities

- Provide a variety of transportation choices

- $\quad$ Make development decisions predictable, fair, and cost effective

- Encourage community and stakeholder collaboration in development decisions (United States Environmental Protection Agency, 2001).

\subsection{The Role of Corporations in achieving Sustainability}

The stakeholder concept has been an ever vogue concept among multi-national corporations. Shrivastava (1995) claims that the corporations have been "environmentally responsible" only when force by regulation. In addition, he states that even the "best" corporations fall short when speaking of ecological sustainability. This ideal is clearly an example of post-modernist thought in terms corporations having a societal responsibility to "stakeholders".

Shrivastava (1995) suggest that corporations must "reconceptualize their role within society". Corporate activities must be linked to all aspects of sustainability. One of the primary reasons for this is because corporations have resources at their disposal to resolve fundamental problems(Shrivastava, 1995, p. 954). These ties into the post-modern organizational concept of stakeholders whereby non-owners believe that have a right to command an entity by virtue of the corporation existence within society.

\section{Issues with Sustainable Development}

\subsection{Vague and numerous definitions}

Two of the biggest points of contention with the concept of sustainable development is that the definition of the term is vague and there are many different definitions that are in use. Bonevac (2010) states that "many environmentalists are troubled by the plethora of understandings of sustainability in the literature. For example, Andrew Dobson counts more than three hundred definitions" (Bonevac, 2010, p. 84). Secondly, Mitcham (1995) states that "Sustainability is one of those ideals which like love or patriotism, points towards something necessary and even noble, but can also readily become a cliché and be misused by ideologues". The author Uwe Porksen has called sustainability a "plastic word", it can mean just about anything (Mitcham, 1995, p. 322). Bonevac (2010) states that "devising criteria and measures of sustainability" has become a cottage industry. This is undoubtedly due to its vague and numerous definitions. Wood (2008) states that one item of note is that how academics are "debunking the myths that sustainability is mostly about the environment and that sustainability is primarily a scientific and technical problem." "Rather in their view, sustainability has over a dozen "social justice aspects" such as environmental racism, fair trade, living wage, domestic partnerships, corporate responsibility, rights of indigenous peoples, gender equality, water rights, human right child labor issues, affirmative action, multicultural competence, pollution and farming practices, worker's rights, sweatshop labor and slavery". Even though the literature is volumous regarding the concept of sustainability, the same literature does not define or explain exactly what are we supposed to be sustaining. 


\subsection{Anticipating the needs of the future}

One of the largest challenges with sustainable development is attempting to meet the needs of the future. Much of the literature has written from the viewpoint of sustainable ecology advocates the net zero usage of natural resources. Since zero reliance upon natural resources is impossible, this environmental goal is not even obtainable. Since this is not the case in the present and natural resources are needed in the present and presumably in the future, one must anticipate the resource needs of the future, according to sustainability doctrine. The next section will cover what history has shown us about the need of natural resources and the influence of technological innovation.

\subsection{What history has Taught Us about Technology Innovations}

History has shown that innovations not often recognized for their potential contributions or worth to society in the future. Below are a couple of examples of this very sediment:

"I think there is a world market for about five computers"-Thomas Watson (CEO of IBM), 1943. (Cerf \& Navasky, 1998, p. 230).

“640k ought to be enough for anybody”-Bill Gates (CEO of Microsoft), 1981(Cerf \& Navasky, 1998, p. 231).

"There is not the slightest indication that [nuclear] energy will ever be obtainable. It would mean that the atom would have to be shattered at will"-Albert Einstein, 1932 (Cerf \& Navasky, 1998, p. 236).

"Everything that can be invented has been invented"-Charles Duell (Commissioner of U.S. Office of Patents urging President McKinley to abolish his office), 1899(Cerf \& Navasky, 1998, p. 225).

The point of this exercise is that some of the most intelligent people have not recognized the value or usefulness of innovations. Why would proponents of sustainable development believe that suddenly be able to recognize innovations and resource needs before they are developed?

\subsection{Diffusion of innovation}

One possible explanation for the difficulty in predicting the needs of the future may be due to the diffusion of innovations theory. This theory seeks to explain how, why and at what rate new ideas and technology spread through cultures (Lima, 2005). Rodgers suggested that there are four main elements that influence the spread of a new idea: the innovation, communication channels, time, and a social system (Rogers, 1995, pp. 11-23). Rogers also defines five characteristics that influence an individual's decision to adopt or reject an innovation. They are relative advantage, compatibility, complexity or simplicity, trialability and observability (Lima, 2005). See Figure 4 for a graphic depiction of Rodger's Diffusion of Innovation.

The importance of this theory in relation to sustainability is that global environment is always changing as is technology and innovations. Not all technology is adopted but not all technologies are rejected. If a technology is adopted, Rodgers suggests that technology commands market share in terms of a normally distributed curve. This may be an over-simplification on the part of Rodgers in that not all technologies follow the same time line, let alone a normal distribution curve. In addition, Rogers illustrates that the adaptation of technologies or innovations is a very complex interaction. Proponents of sustainable development do not address this issue.

\subsection{Indicators of technology innovations}

The number of patents issued by the United States could be an indicator of how fast technology is changing. In 1900 , there were around 25,000 patents issued. In 1950, there were around 43,000 patents issued. By 1997, the number of patents has nearly tripled to around 150,000 patents (Moore \& Simon, 1999, p. 23). Furthermore, when examining the patents issued from 1963 to 2009, the number of applications has increased more than four fold. See Figure 5 for a graphical depiction of this trend.

\section{Discussion}

This examination of the concept of sustainability, history behind the concept and what proponents of sustainability are using it today. In addition, we explored the various problems associated with this concept such as vague definition and multiple definitions. These problems are further complicated by the fact that a major component of sustainability is that resource control for present and future generations (id est resource, technology and income redistribution). Figuring out the needs of the present generation does not present a problem; however, trying to estimate the needs of future generations is nearly impossible. The evidence shows that some of the most intelligent people on earth were unable to see the value of various new technologies. In addition, the rates at which innovations are produced within the United States have increased significantly. One area of future research could be to track the development of numerous innovations from initial invention to 
acceptance. The literature is lacking when it comes to how many inventions make out of the early phase of the innovative process. Another possible area of future research is to follow innovations with regards how needs change with regards to inventions evolving from their initial forms to more advanced forms. This change will certain reflect a change in raw material needs for the advanced forms of the innovation. This will provide two useful pieces of information, how does the initial innovation change over time and how does the innovation's needs change. A third avenue of research could consist of utilizing a cost benefit analysis as another method to verify that the cost of sustainability outweigh the benefits. This may prove to be a daunting task due the sustainability not being a well-defined concept.

The notion of sustainability is a noble thought; however with the various problems associated with this concept, the effort put forth utilizing this notion is a wasted effort.

\section{References}

Bonevac, D. (2010). Is Sustainability Sustainable? Acad. Quest., 23(1), 84-101. http://dx.doi.org/10.1007/s12129-009-9152-4

Cerf, C., \& Navasky, V. (1998). The Experts Speak-The Definitive Compendium of Authoritative Misinformation (Vol. 2nd). New York, NY: Pantheon Books.

Cone, M. (2010, December 1). EPA Launches Sustainable Reform Effort. [Online] Available: http://www.scientificamerican.com/article.cfm?id=epa-launches-sustainability-reform-effort (May 29, 2011)

Ehrlich, P. R. (1968). The Population Bomb. New York, NY: Ballantine Books.

Ehrlich, P. R., \& Ehrlich, A. H. (2009). The Population Bomb Revisited. The Electronic Journal of Sustainable Development, 1(3), 63-71.

Lima, M. (2005, February 20). Diffusion of Innovation Theory. [Online] Available: http://a.parsons.edu/ limam240/thesis/documents/Diffusion_of_Innovations.pdf (May 8, 2011)

Malthus, T. R. (1826). An Essay on the Principle of Population. [Online] Available: http://www.econlib.org/library/Malthus/malPlong.html (August 22, 2010)

McDonough, W., \& Braungart, M. (2003). The Hannover Principles-Design for Sustainability. New York: William McDonough + Partners.

Meadows, D. (2004). The Limits of Growth (3rd ed.). White River Junction, VT: Chelsea Green Publishing.

Mitcham, C. (1995). The Concept of Sustainable Development: its Origins and Ambivalence. Technology in Society, 331-326. http://dx.doi.org/10.1016/j.physletb.2003.10.071

Moore, S., \& Simon, J. L. (1999, December 15). The Greatest Century That Ever Was: 25 Miraculous Trends of the Past 100 Years. Policy Analysis, 364, 32.

Morris, J. (2002). Sustainable Development Promoting progress or perpetuating poverty. London: Profile Books.

National Science Board. (n.d). Science and Engineering Indicators 2008. [Online] Available: http://www.nsf.gov/statistics/seind08/ (May 28, 2011)

Patent Technology Monitoring Team. (2011, May 27). U.S. Patent Statistics Chart. [Online] Available: http://www.uspto.gov/web/offices/ac/ido/oeip/taf/us_stat.htm (May 28, 2011)

Pigou, A. C. (1912). Wealth and Welfare. London, England: Macmillian and Company Ltd.

Rogers, E. M. (1995). Diffusion of Innovations (4th ed.). New York, NY: The Free Press.

Shrivastava, P. (1995). The Role of Corporations in Achieving Ecological Sustainability. The Academy of Management Review, 20(4), 936-960. [Online] Available: http://www.jstor.org/stable/258961

Taylor, J. (2002). Sustainable Development: A Dubious Solution in search of a Problem. Policy Analysis, 1-49.

United Nations Environment Programme. (1992). Rio Declaration on Environment and Development. [Online] Available: http://www.unep.org/Documents.Multilingual/Default.asp?documentid=78\&articleid=1163 (August 23, 2010)

United States Environmental Protection Agency. (2001, April). What is Smart Growth. [Online] Available: http://www.epa.gov/smartgrowth/pdf/whtissg4v2.pdf (May 15, 2011)

Wall Street Journal Editioral Staff. (2009, May 26). Malaria, Politics and DDT. The Wall Street Journal, p. A15. 
Williamson, H. F. (1945, May). Prophecies of Scarcity or Exhaustion of Natural Resouces in the United States. The American Economic Review, 35(2), 97-145. [Online] Available: http://www.jstor.org/stable/1818434

Wood, P. (2008, April 28). Sustainability's Third Circle. [Online] Available: http://insidehighered.com/layout/set/print/views/2008/04/28/wood (May 8, 2011)

World Commission On Environment and Development. (1987). Our Common Future. Oxford University Press, USA.

\section{The Three Spheres of Sustainability}

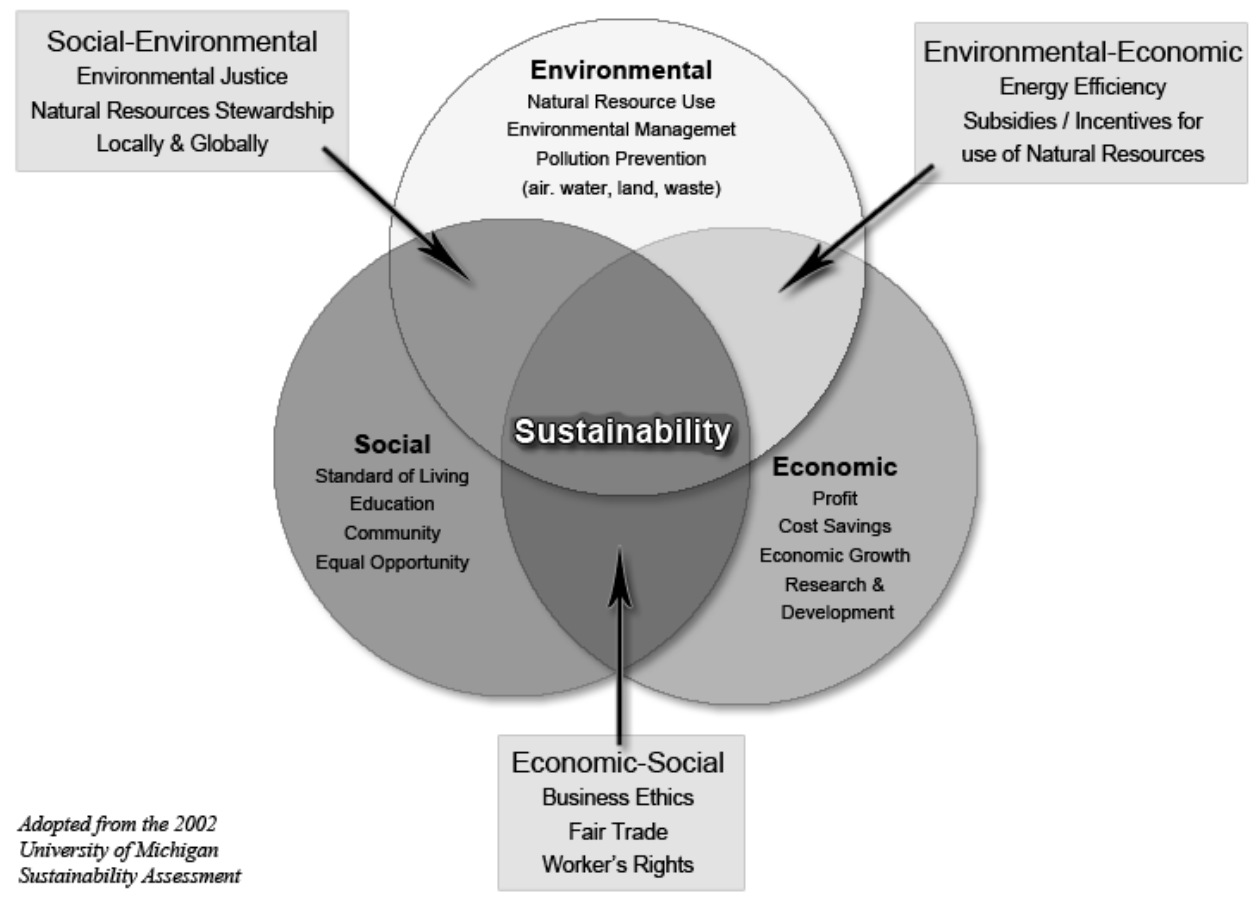

Figure 1. Graphic depiction of sustainability

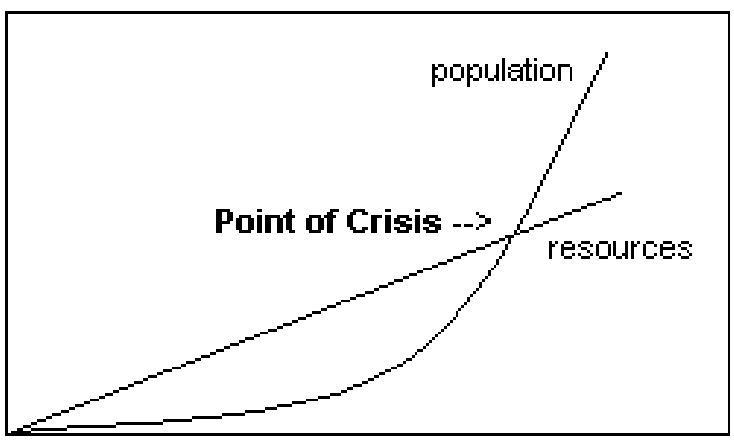

Malthus' Basic Theory

Figure 2. Thomas Malthus Population theory 


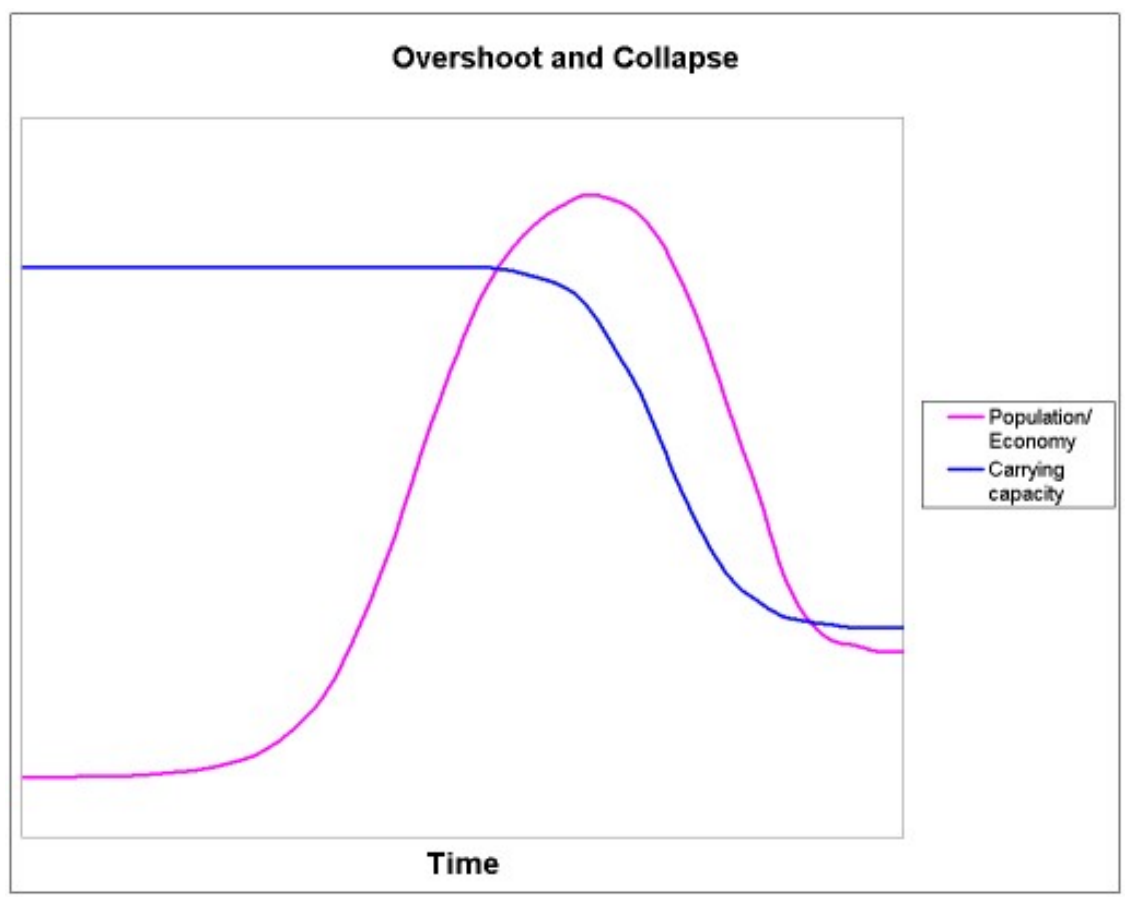

Figure 3. The Limits of Growth per Meadows

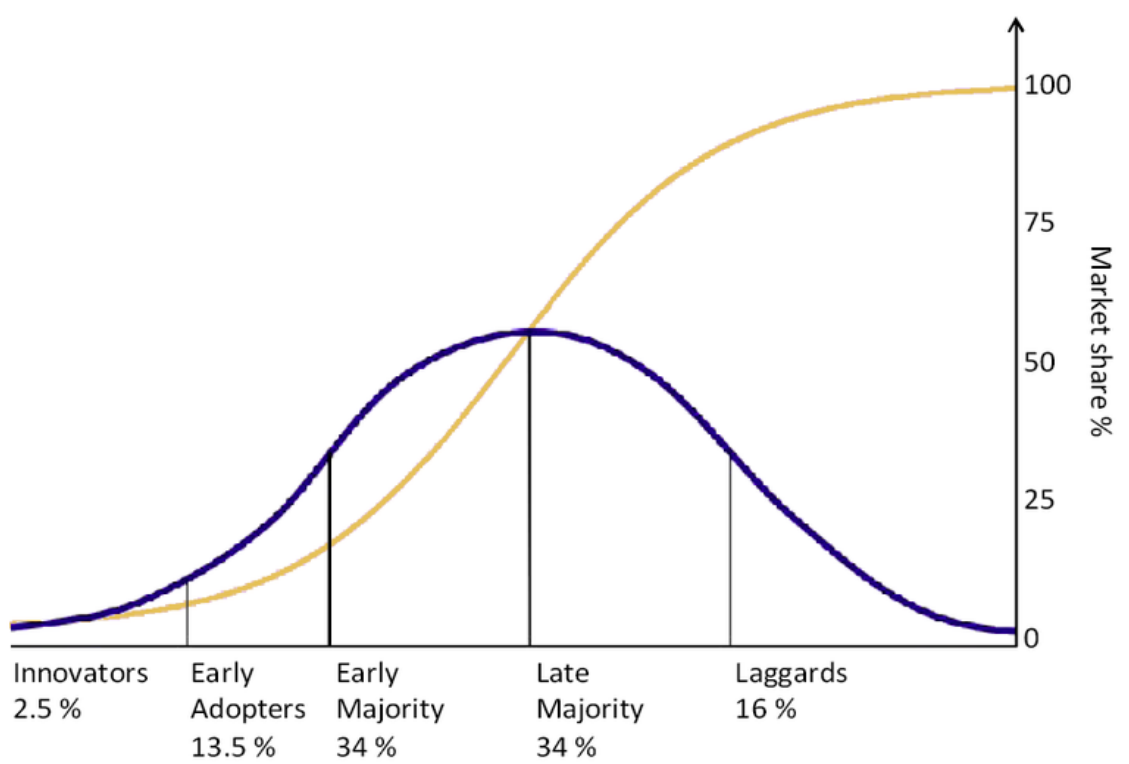

Figure 4. Rogers' Diffusion of Innovation 


\section{U.S. Patent Applications 1963 to 2009}

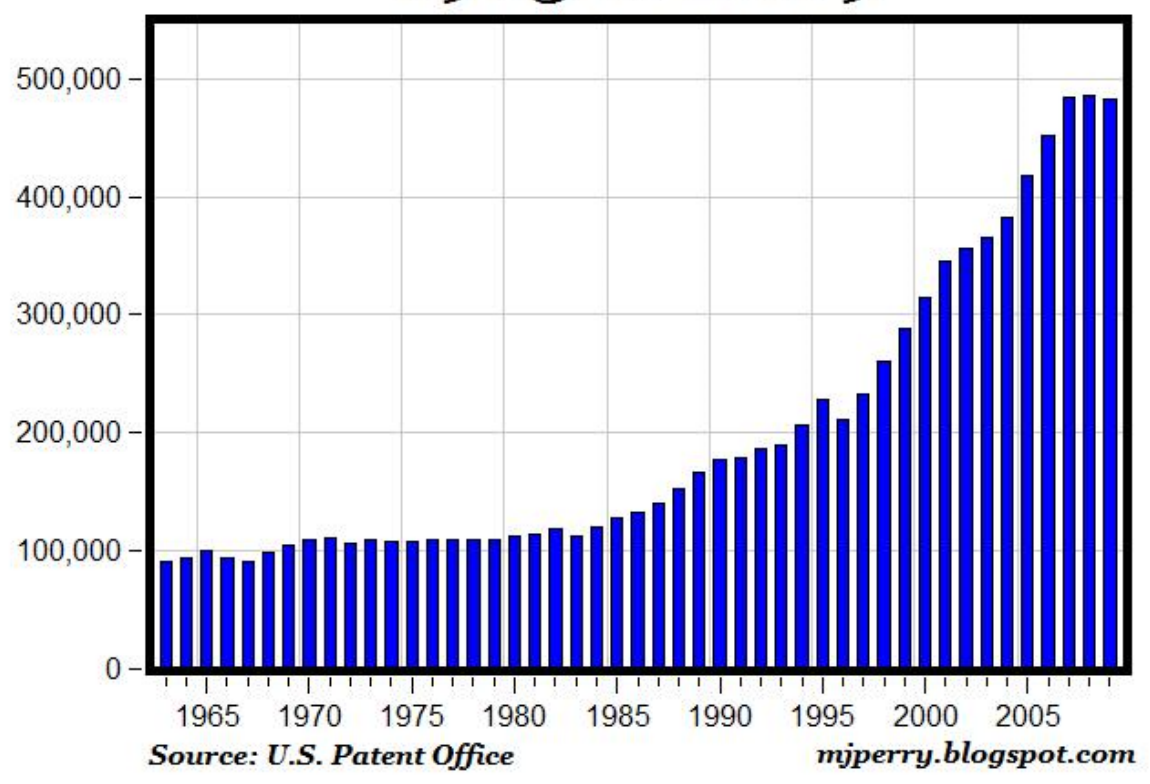

Figure 5. U.S. Patent Applications 1963-2009 